\title{
Characterization of an Actinobacillus Isolated from the Sow Vagina
}

\author{
RICHARD F. ROSS, JAMES E. HALL, ANN P. ORNING, and STEVEN E. DALE \\ Veterinary Medical Research Institute, College of Veterinary Medicine, \\ Iowa State University, Ames, Iowa 50010
}

\begin{abstract}
The growth characteristics, morphology, and biochemical activity of four strains of a hemolytic, urease-positive, gram-negative organism isolated from vaginal exudate of postparturient sows closely resembled those of organisms belonging to the genus Actinobacillus. Comparison by agglutination, immunodiffusion, and electrophoresis in acrylamide gel revealed that the four strains were identical. They were distinguished from $A$. lignieresii, A. equuli, A. seminis, $A$. suis, and other members of the family Brucellaceae by means of these three techniques. The four strains were related antigenically to all strains of the genus Actinobacillus examined, but were related most closely to $A$. seminis and $A$. suis. The antigenic relatedness and other similarities support inclusion of the organism in the genus Actinobacillus. Its biochemical, antigenic, and electrophoretic differences from established species of the genus Actinobacillus support the conclusion that this swine actinobacillus is a new species. A species name is not proposed for this organism because of the present uncertain taxonomic status of related actinobacilli. The swine actinobacillus persisted in the vagina of two sows for at least 40 days after intravaginal inoculation; however, proof that vaginal infection with the organism causes urogenital disorders of any type has not been obtained. Intraperitoneal and intravenous inoculation of four 6-week-old colostrum-deprived pigs with the organism resulted in no clinical or postmortem evidence of disease. Strain 192 (= ATCC $27072=$ NCTC 10801) is the representative strain of this group of swine actinobacilli.
\end{abstract}

Members of the genus Actinobacillus commonly are isolated from domestic livestock such as cattle, horses, and sheep but are only occasionally isolated from swine. Diseases in swine from which actinobacilli have been isolated include metritis (3), arthritis $(5,10$, 12), septicemia $(10,12,13)$, nephritis (5), pneumonia (10), hepatitis (10), pericarditis (10), and endocarditis (1,4). Gram-negative, gas-producing bacteria isolated from the intestinal contents of normal swine were identified as actinobacilli by Dickinson and Mocquot (2). This is somewhat surprising since gas production from carbohydrates is not a recognized characteristic of established species of the genus Actinobacillus.

Van Dorssen and Jaartsveld proposed the name $A$. suis for hemolytic actinobacilli of swine origin in 1962 (10). Zimmermann proposed the same name for similar strains in 1964 (13). Wetmore et al. identified hemolytic isolates recovered from irradiated swine as $A$. lignieresii (12). Because of cultural and biochemical similarities, Mraz (7) identified both $A$. suis and the strains isolated by Wetmore et al. as $A$. equuli. He further concluded that differences in host specificity, hemolysin production, and lactose fermentation were sufficient to retain $A$. equuli as a species distinct from $A$. lignieresii. However, Wetmore et al. (12) concluded that the biochemical and serologic differences between $\boldsymbol{A}$. lignieresii and $A$. equuli were insufficient to warrant existence of two species. It appears that, although Actinobacillus isolates of swine origin are related to existing species of that genus, their taxonomic status within the genus is still not clear.

In recent work done in our laboratory, a hemolytic, urease-positive, gram-negative organism isolated from vaginal exudate of postparturient sows was tentatively identified as an actinobacillus (9). It is the purpose of the present work to characterize further the Acti- 
nobacillus-like organisms of sow vaginal origin and to compare them with the presently recognized species of actinobacilli.

\section{MATERIALS AND METHODS}

Bacterial strains. Information regarding the strains used in this study is given in Table 1. The four swine strains were isolated from sows on three different farms.

Media and biochemical procedures. All culture media were prepared from dehydrated ingredients (Difco) unless otherwise indicated. Cultures were grown in Brain Heart Infusion supplemented with 5\% fresh rabbit serum (BrHI-RS) except that cells grown for deoxycholate or phenol-acetic acid extraction were grown in Brain Heart Infusion supplemented with $1 \%$ peptone (BrHI-P). Colonial morphology and hemoly tic activity were determined on Tryptose blood-agar base with $5 \%$ horse blood. All agar cultures were incubated in $5 \% \mathrm{CO}_{2}$ at $37 \mathrm{C}$ in a high-humidity incubator (National Appliance Company, Portland, Ore.).

Carbohydrate utilization was determined in phenol red broth base containing $0.5 \%$ of the appropriate carbohydrate. Other biochemical activities were determined in urea agar, nitrate agar, litmus milk, Simmons' citrate agar, gelatin, and methyl red-Voges-Proskauer

TABLE 1. Identification and source of strains

\begin{tabular}{|c|c|c|}
\hline Strain & Source & Received from \\
\hline \multicolumn{3}{|c|}{$\begin{array}{l}\text { Swine actinobacillus } \\
\text { strains }^{a}\end{array}$} \\
\hline 63 & Porcine & Authors \\
\hline 145 & Porcine & Authors \\
\hline 192 & Porcine & Authors \\
\hline 200 & Porcine & Authors \\
\hline \multicolumn{3}{|l|}{ Actinobacillus } \\
\hline 1388 & Porcine & WRAIR $^{b}$ \\
\hline 13369 & Bovine & $\operatorname{ATCC}^{c}$ \\
\hline 13371 & Bovine & ATCC \\
\hline 13372 & Bovine & ATCC \\
\hline \multicolumn{3}{|l|}{ A. equuli } \\
\hline 13376 & Equine & ATCC \\
\hline \multicolumn{3}{|l|}{ A. seminis } \\
\hline $\begin{array}{l}15768 \\
\text { Asuis }\end{array}$ & Ovine & ATCC \\
\hline 7038 & Porcine & C. A. Van Dorssen \\
\hline \multicolumn{3}{|l|}{$\begin{array}{l}\text { Pasteurella } \\
\text { haemolytica }\end{array}$} \\
\hline $\begin{array}{l}1063 \\
P . \text { multocida }\end{array}$ & Bovine & K. L. Heddleston \\
\hline $\begin{array}{l}934 \\
\text { Moraxello bovis }\end{array}$ & Porcine & K. L. Heddleston \\
\hline $\begin{array}{l}\text { Ep } 300 \\
\text { Brucella suis }\end{array}$ & Bovine & G. W. Pugh \\
\hline 1330 type D & Porcine & B. L. Deyoe \\
\hline
\end{tabular}

${ }^{a}$ Isolated from vaginal exudate.

$b$ Walter Reed Army Institute of Research, Washington, D.C.

${ }^{c}$ American Type Culture Collection, Rockville, Md. medium. Indole formation was determined in 24-hr cultures in SIM medium and Trypticase nitrate broth (BBL) with chloroform and Kovac's reagent. Cultures grown in Trypticase nitrate broth were also extracted with ether and tested with Ehrlich's reagent, with and without saturated potassium persulfate. $\mathrm{H}_{2} \mathrm{~S}$ production was determined with SIM medium and with lead acetate-soaked paper strips suspended over Tryptose phosphate broth cultures.

Microscopy. Cellular morphology was detected by light microscopic examination of Gram-stained 24-hr blood-agar cultures. Motility was determined by light and phase-contrast microscopic examination of cultures grown for $18 \mathrm{hr}$ in BrHI-RS.

Antigen preparation. Whole-cell antigens were grown for $24 \mathrm{hr}$ on horse blood-agar, harvested in $0.85 \% \mathrm{NaCl}$ containing $0.25 \%$ Formalin, centrifuged, washed twice, and stored in the same solution at $4 \mathrm{C}$. The antigen concentration was adjusted to an optical density of 0.42 at $550 \mathrm{~nm}$ with a spectrophotometer (Coleman Jr.; Coleman Instruments, Inc., Maywood, III.).

Cultures for soluble antigen preparation were grown for $24 \mathrm{hr}$ in BrHI-P. The cells were harvested by centrifugation, suspended in $0.85 \% \mathrm{NaCl}$, and extracted with $1 \%$ sodium deoxycholate (11).

Electrophoresis of cell proteins in polyacrylamide was performed by a procedure similar to that described for use with mycoplasmas (8). Cells grown for $24 \mathrm{hr}$ in $\mathrm{BrHI}-\mathrm{P}$ were harvested by centrifugation and washed twice with $0.25 \mathrm{M} \mathrm{NaCl}$. Approximately $0.30 \mathrm{~g}$ of cell paste was suspended in $1 \mathrm{ml}$ of $0.25 \mathrm{M}$ $\mathrm{NaCl}$. The cells were solubilized by adding two volumes of phenol-acetic acid-water $(2: 1: 0.5, \mathrm{w} / \mathrm{v} / \mathrm{v})$ to one volume of cell suspension. Equal volumes of the extracts were mixed with a sucrose-acetic acid solution $(40 \mathrm{~g}$ of sucrose, $35 \mathrm{ml}$ of acetic acid, and 65 ml of water). A $100-\mu$ liter amount of this mixture was layered on a polyacrylamide gel and subjected to electrophoresis for $3 \mathrm{hr}$ at $3.5 \mathrm{ma}$ per gel in $10 \%$ acetic acid with a disc electrophoresis apparatus (Polyanalyst; Buchler Instruments, Inc., Fort Lee, N. J.). The gels were stained for $1 \mathrm{hr}$ with $1 \%$ amido black and destained for $3 \mathrm{hr}$ at $10 \mathrm{ma}$ per gel.

Antiserum production. Rabbit antisera for agglutination tests were produced with a series of seven intravenous injections of Formalin-killed $(0.25 \%)$ whole-cell suspensions.

Rabbit antisera for immunodiffusion were prepared with a series of four subcutaneous injections of sodium deoxycholate extracts with incomplete Freund adjuvant (Difco).

Serologic procedures. Agglutination tests were done on a warm glass plate with whole-cell suspensions (optical density 0.42 ) and dilutions of the antisera. Serum-cell mixtures were agitated by rotation of the plate, and the reactions were read after incubation for $4 \mathrm{~min}$ at room temperature.

Immunodiffusion was performed in $0.5 \%$ Ionagar (Consolidated Laboratories, Chicago Heights, III.) in $0.85 \%$ saline.

Swine inoculation. Strain 192 was inoculated into the yolk sac of 7-day-old embryonating hen's eggs. The organism killed the chick embryos within 24 to $48 \mathrm{hr}$. Chorioallantoic and yolk sac fluids were 
collected, checked for purity on blood-agar, and used for inoculation of swine.

Two multiparous, nonpregnant sows were placed in isolation and fed standard rations devoid of antibiotics. Samples of vaginal secretions collected from both sows before inoculation were negative for actinobacilli. The sows were inoculated intravaginally by insertion of a cotton-tipped applicator soaked with infective yolk sac fluid. Samples of vaginal secretions were periodically collected with sheathed applicators (Falcon Plastics, Division of BioQuest, Los Angeles, Calif.) and inoculated on blood-agar.

Cesarean-derived, colostrum-deprived swine were reared on commercial sow milk replacer (SPF-Lac; Borden Chemical Co., Smith-Douglass Division, Norfolk, Va.) and commercial swine ration. The ration contained antibiotics until 1 week before inoculation of the swine. Two 6-week-old, cross-bred swine were inoculated intraperitoneally with $1 \mathrm{ml}$ of chorioallantoic fluid containing strain 192, and two littermates were inoculated intravenously with $1 \mathrm{ml}$ of the same inoculum.

\section{RESULTS}

The four swine strains produced small, grayish-white, smooth, convex colonies, 1 to 2 $\mathrm{mm}$ in diameter on $5 \%$ horse blood-agar, within $24 \mathrm{hr}$ of incubation. A narrow zone of betahemolysis was observed around the colonies. The four strains grew on MacConkey agar.

The organisms grew poorly on blood-agar under aerobic conditions but were stimulated by $5 \% \mathrm{CO}_{2}$. They also grew fairly well anaerobically.

The swine strains produced diffuse heavy growth in BrHI-RS medium within $24 \mathrm{hr}$ of incubation. After incubation for an additional $24 \mathrm{hr}$, a granular (strains 63 and 200) or smooth (strains 145 and 192) sediment formed in the bottom of the culture tubes. All four isolates were nonmotile.

Light microscopic examination of cultures

TABLE 2. Biochemical characteristics of the swine actinobacillus strains, known actinobacillus strains, and Pasteurella haemolytica

\begin{tabular}{|c|c|c|c|c|c|c|c|c|c|c|c|c|}
\hline \multirow[b]{2}{*}{ Media } & \multicolumn{4}{|c|}{ Swine isolates } & \multirow{2}{*}{$\begin{array}{c}\text { A. } \\
\text { suis } \\
7038\end{array}$} & \multicolumn{4}{|c|}{ A. lignieresii } & \multirow{2}{*}{$\begin{array}{c}A . \\
\text { equuli } \\
13376\end{array}$} & \multirow{2}{*}{$\begin{array}{c}A . \\
\text { seminis } \\
15768 \\
\end{array}$} & \multirow{2}{*}{$\begin{array}{l}\text { P. haemo } \\
\text { lytica } \\
1063\end{array}$} \\
\hline & 145 & 63 & 192 & 200 & & 1388 & 13369 & 13371 & 13372 & & & \\
\hline Glucose $^{a}$ & $\mathbf{A}^{b}$ & A & A & A & A & A & A & A & A & A & A & $\mathbf{A}$ \\
\hline Lactose & $\mathrm{O}$ & 0 & 0 & o & A & A & A & o & A & A & 0 & A \\
\hline Sucrose & $\mathrm{O}$ & 0 & 0 & $\mathrm{O}$ & A & A & A & A & A & A & 0 & A \\
\hline Maltose & o & o & o & o & A & A & A & A & A & A & 0 & A \\
\hline Mannitol & A & A & A & A & o & 0 & A & A & A & A & $\mathrm{O}$ & A \\
\hline Salicin & $\mathrm{O}$ & 0 & 0 & 0 & A & A & 0 & $\mathrm{O}$ & $\mathrm{O}$ & o & 0 & o \\
\hline Aesculin & $\mathrm{O}$ & 0 & o & O & o & 0 & $\mathrm{O}$ & o & o & o & O & o \\
\hline Adonitol & $\mathrm{O}$ & $\mathrm{o}$ & 0 & $\mathrm{O}$ & $\mathrm{O}$ & 0 & 0 & $\mathrm{O}$ & $\mathrm{O}$ & $\mathrm{O}$ & 0 & o \\
\hline Dulcitol & $\mathrm{O}$ & 0 & $\mathrm{O}$ & $\mathrm{o}$ & $\mathrm{O}$ & $\mathrm{O}$ & $\mathrm{O}$ & $\mathrm{O}$ & $\mathrm{O}$ & $\mathrm{O}$ & 0 & $\mathrm{O}$ \\
\hline Inulin & o & 0 & $\mathrm{O}$ & o & O & 0 & $\mathrm{O}$ & o & o & o & 0 & o \\
\hline Inositol & A & A & A & A & $\mathrm{O}$ & 0 & 0 & $\mathrm{O}$ & $\mathrm{O}$ & $\mathrm{O}$ & 0 & A \\
\hline Sorbitol & A & A & A & A & $\mathrm{O}$ & 0 & $\mathrm{O}$ & $\mathrm{O}$ & $\mathrm{O}$ & A & $\mathrm{O}$ & A \\
\hline Raffinose & o & 0 & 0 & o & A & 0 & $\mathrm{o}$ & A & o & A & 0 & A \\
\hline Trehalose & $\mathrm{O}$ & 0 & 0 & $\mathrm{O}$ & A & A & $\mathrm{O}$ & $\mathrm{O}$ & $\mathrm{O}$ & o & 0 & $\mathrm{O}$ \\
\hline Arabinose & A & A & A & A & A & A & O & o & $\mathrm{O}$ & $\mathrm{o}$ & 0 & 0 \\
\hline Rhamnose & A & A & A & A & 0 & 0 & 0 & $\mathrm{o}$ & o & o & 0 & $\mathrm{O}$ \\
\hline Xylose & A & A & A & A & A & A & A & A & A & A & $\mathrm{O}$ & A \\
\hline Galactose & A & A & A & A & A & A & A & A & A & A & 0 & A \\
\hline Mannose & A & $\mathrm{A}$ & A & A & A & A & A & A & A & A & $\mathrm{O}$ & $\mathrm{O}$ \\
\hline Urease & + & + & + & + & + & + & + & + & + & + & - & - \\
\hline Nitrate & + & + & + & + & + & + & + & + & + & + & - & + \\
\hline Indole & - & - & - & - & - & - & - & - & - & - & - & - \\
\hline Catalase & + & + & + & + & + & + & - & - & - & - & + & + \\
\hline Gelatinase & $\mathrm{O}$ & $\mathrm{O}$ & $\mathrm{o}$ & $\mathrm{O}$ & $\mathrm{O}$ & $\mathrm{O}$ & $\mathrm{O}$ & $\mathrm{O}$ & $\mathrm{O}$ & $\mathrm{O}$ & $\mathrm{O}$ & $\mathrm{O}$ \\
\hline Litmus milk & $\mathrm{O}$ & $\mathrm{O}$ & $\mathrm{O}$ & $\mathrm{o}$ & A & A & $\mathrm{o}$ & $\mathrm{o}$ & A & A & $\mathrm{o}$ & $\mathrm{O}$ \\
\hline $\mathrm{H}_{2} \mathrm{~S}$ & + & + & + & + & + & + & + & + & + & + & + & + \\
\hline Citrate & $\mathrm{O}$ & 0 & $\mathrm{o}$ & $\mathrm{O}$ & $\mathrm{O}$ & $\mathrm{o}$ & 0 & $\mathrm{O}$ & $\mathrm{O}$ & o & $\mathrm{o}$ & $\mathrm{O}$ \\
\hline Methyl red & - & - & - & - & - & - & - & - & - & - & - & - \\
\hline Voges-Proskauer & - & - & - & - & - & - & - & - & - & - & - & - \\
\hline
\end{tabular}

${ }^{a}$ Carbohydrate fermentations were determined after 7 days incubation at $37 \mathrm{C}$.

$b$ A, acid; $\mathrm{O}$, no change; + , positive; - , negative. 
grown on $5 \%$ horse blood-agar revealed small, gram-negative, pleomorphic rod-shaped to coccoid organisms. The cells were arranged in pairs, short chains, or masses. Considerable variability in staining intensity was observed.

The results obtained from various biochemical tests are given in Table 2 . The swine isolates produced acid from glucose, mannitol, glycerol, inositol, sorbitol, arabinose, rhamnose, xylose, galactose, and mannose. They did not produce gas from glucose, and they failed to produce acid from lactose, sucrose, maltose, salicin, aesculin, adonitol, dulcitol, inulin, raffinose, or trehalose after 7 days at $37 \mathrm{C}$. The strains reduced nitrates to nitrites, produced catalase, and were urease-positive. $\mathrm{H}_{2} \mathrm{~S}$ production was not detected in SIM medium, but slight to moderate production was detected from all organisms with lead acetate paper strips. The strains did not produce indole, alter litmus milk, utilize citrate, liquefy gelatin, or produce acetylmethylcarbinol; they were negative for the methyl red test.

All four strains were closely related antigenically as determined by agglutination, and they cross-reacted to varying degrees with $A$. suis, A. seminis, and bovine and swine strains of A. lignieresii (Table 3 ). Sera collected from all rabbits before immunization did not agglutinate any of the antigens.

Immunodiffusion with deoxycholate extracts and rabbit antisera revealed that the four strains were antigenically very similar (Fig. 1). The strains shared two or three antigens with $A$. seminis, $A$. lignieresii, and $A$. suis and one antigen each with $A$. equuli and Pasteurella haemolytica (Fig. 2 and 3 ).

The four strains were electrophoretically identical (Fig. 4) but were distinguishable on this basis from other strains of actinobacilli (Fig. 5 and 6). Three bovine strains of $A$. lignieresii [ATCC (American Type Culture

TABLE 3. Antigenic relationship of swine actinobacillus-like (ABL) organisms to established Actinobacillus species and other Brucellaceae as determined by agglutination

\begin{tabular}{|c|c|c|c|c|c|c|c|c|c|c|c|}
\hline \multirow[b]{3}{*}{ Antigens } & \multicolumn{11}{|c|}{ Agglutination titers ${ }^{a}$ with rabbit antisera } \\
\hline & \multicolumn{4}{|c|}{$\mathrm{ABL}$ isolates } & \multicolumn{4}{|c|}{ A. lignieresii } & \multirow{2}{*}{$\begin{array}{c}A . \\
\text { seminis } \\
15768\end{array}$} & \multirow{2}{*}{$\begin{array}{c}\text { A. } \\
\text { suis } \\
7038\end{array}$} & \multirow{2}{*}{$\begin{array}{c}\text { A. } \\
\text { equuli } \\
13376\end{array}$} \\
\hline & 63 & 145 & 192 & 200 & 1388 & 13369 & 13371 & 13372 & & & \\
\hline $\mathrm{ABL}$ isolates & & & & & & & & & & & \\
\hline 63 & 320 & 640 & 320 & 320 & 160 & 40 & 40 & $0^{b}$ & 0 & 80 & 0 \\
\hline 145 & 320 & 1,280 & 320 & 640 & 160 & 80 & 80 & 2 & 20 & 160 & 0 \\
\hline 192 & 320 & 1,280 & 640 & 640 & 160 & 80 & 80 & 0 & 20 & 160 & 0 \\
\hline 200 & 640 & 640 & 320 & 1,280 & 160 & 80 & 80 & 0 & 0 & 160 & 0 \\
\hline A. suis & & & & & & & & & & & \\
\hline 7038 & 2 & 160 & 160 & 320 & 640 & 80 & 80 & 80 & 2 & 1,280 & 0 \\
\hline A. lignieresii & & & & & & & & & & & \\
\hline 1388 & 2 & 80 & 80 & 80 & 640 & 40 & 40 & 80 & 2 & 640 & 0 \\
\hline 13369 & 0 & 0 & 0 & 0 & 0 & 320 & 0 & 2 & 0 & 160 & 0 \\
\hline 13371 & 0 & 0 & 0 & 0 & 0 & 0 & 640 & 0 & 0 & 0 & 0 \\
\hline 13372 & 2 & 2 & 2 & 20 & 40 & 2 & 2 & 160 & 0 & 160 & 0 \\
\hline A. equuli & & & & & & & & & & & \\
\hline $\begin{array}{c}13376 \\
\text { A. seminis }\end{array}$ & 0 & 0 & 0 & 0 & 0 & 0 & 0 & 0 & 0 & 0 & 40 \\
\hline 15768 & 0 & 0 & 0 & 0 & 0 & 0 & 0 & 0 & 1,280 & 0 & 0 \\
\hline $\begin{array}{l}\text { Pasteurella } \\
\text { haemo- } \\
\text { lytica }\end{array}$ & & & & & & & & & & & \\
\hline $\begin{array}{l}1063 \\
\text { P. multocida }\end{array}$ & 0 & 0 & 0 & 0 & 0 & $\mathrm{NT}^{c}$ & 0 & NT & 0 & 0 & NT \\
\hline $\begin{array}{l}934 \\
\text { Brucella suis }\end{array}$ & 0 & 0 & 0 & 0 & 0 & NT & 0 & NT & 0 & 0 & NT \\
\hline $\begin{array}{c}1330 \\
\text { Moraxella }\end{array}$ & 0 & 0 & 0 & 0 & 0 & NT & 0 & NT & 0 & 0 & NT \\
\hline $\begin{array}{l}\text { bovis } \\
\text { Ep300 }\end{array}$ & 0 & 0 & 0 & 0 & 0 & NT & 0 & NT & 0 & 0 & NT \\
\hline
\end{tabular}

${ }^{a}$ Reciprocal of the highest serum dilution agglutinating the test antigen.

$b$ No agglutination with undiluted serum.

$c$ Not tested. 


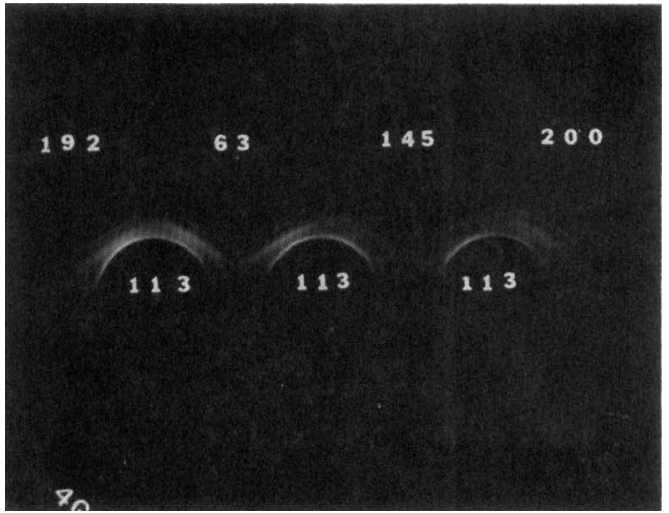

FIG. 1. Immunodiffusion patterns obtained with deoxycholate extracts of four actinobacillus strains $(192,63,145$, and 200) and antiserum (113) against Actinobacillus-like strain 192.

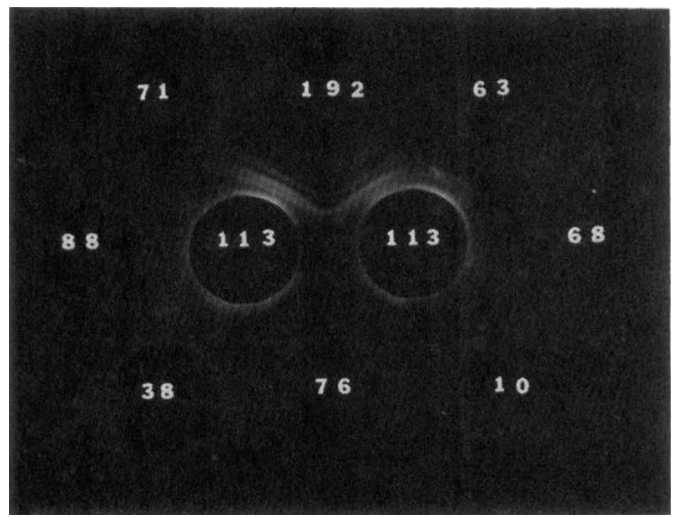

FIG. 2. Immunodiffusion patterns obtained with deoxycholate extracts of two actinobacillus strains, six other strains of the family Brucellaceae, and antiserum (113) against strain 192. Symbols for extracts: 63, strain $63 ; 192$, strain 192; 71, A. lignieresii 13371; 88, A. lignieresii 1388; 38, A. suis 7038; 76, A. equuli 13376; 10, Pasteurella haemolytica 1063; and 68, $A$. seminis 15768 .

Collection) 13369, ATCC 13371, and ATCC 13372] were electrophoretically very similar but distinct from $A$. lignieresii 1388. $A$. lignieresii 1388 was identical to $A$. suis (Fig. 5). Extracts of $A$. equuli, $A$. seminis, Pasteurella multocida, and $P$. haemolytica each formed distinct electrophoretic patterns (Fig. 6).

Intraperitoneal and intravenous inoculation of chorioallantoic fluid-containing strain 192 in young swine resulted in no temperature elevations or other evidence of illness. Necropsy of one intraperitoneally infected swine and one intravenously infected swine 5 days postinoculation revealed no gross lesions. Identical observations were made on two swine necropsied 8 days postinoculation. No bacteria were recovered from the livers, kidneys, spleens, heart blood, brains, tarsal joints,

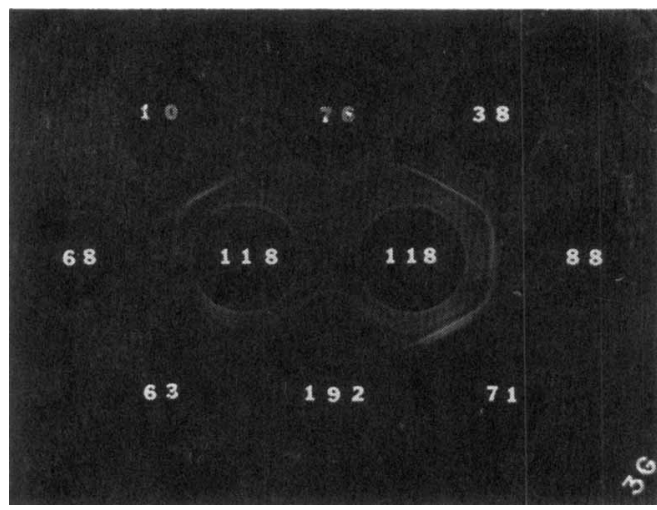

FIG. 3. Immunodiffusion patterns obtained with deoxycholate extracts of two actinobacillus strains, six other strains of the family Brucellaceae, and antiserum (118) against A. lignieresii 13371. Symbols for extracts: 63 , strain 63; 192, strain 192; 71, $A$. lignieresii 13371; 88, A. lignieresii 1388; 38, A. suis 7038; 76, A. equuli 13376; 10, Pasteurella haemolytica 1063; and 68, A. seminis 15768 .

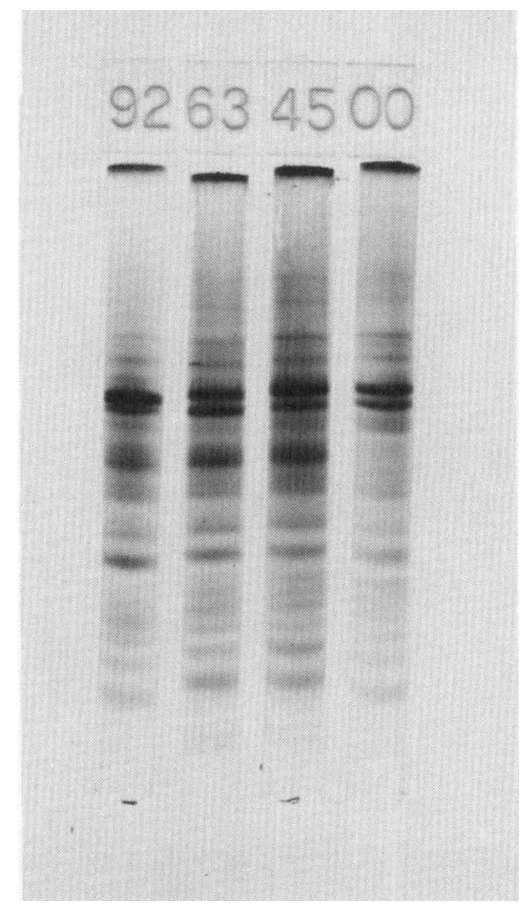

FIG. 4. Electrophoretic patterns of cell proteins from strains 192 (92), 63 (63), 145 (45), and 200 (00). 


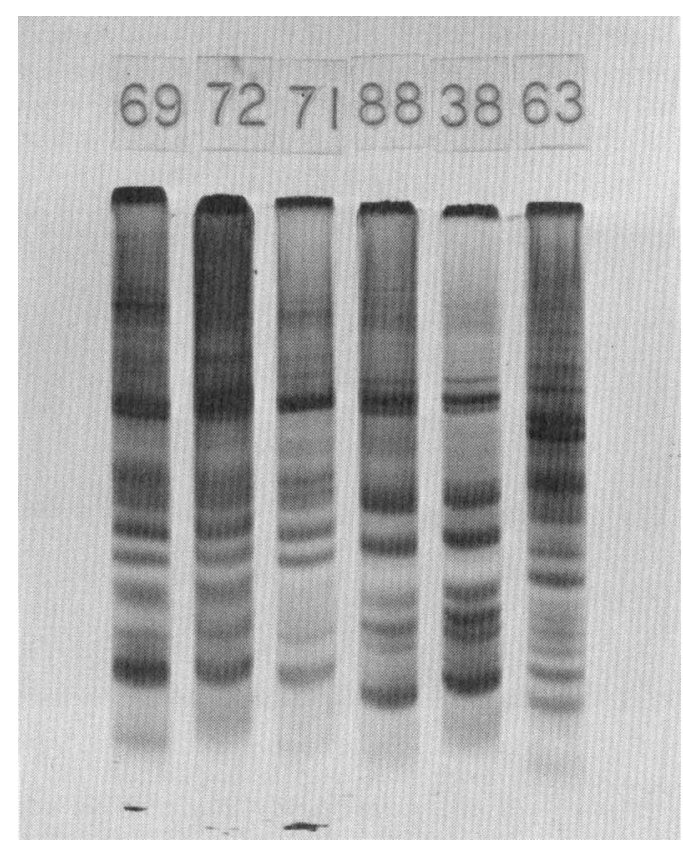

FIG. 5. Electrophoretic patterns of cell proteins from Actinobacillus lignieresii 13369 (69) and 13371 (71), A. lignieresii 1388 (88), A. suis 7038 (38), and swine strain 63 (63).

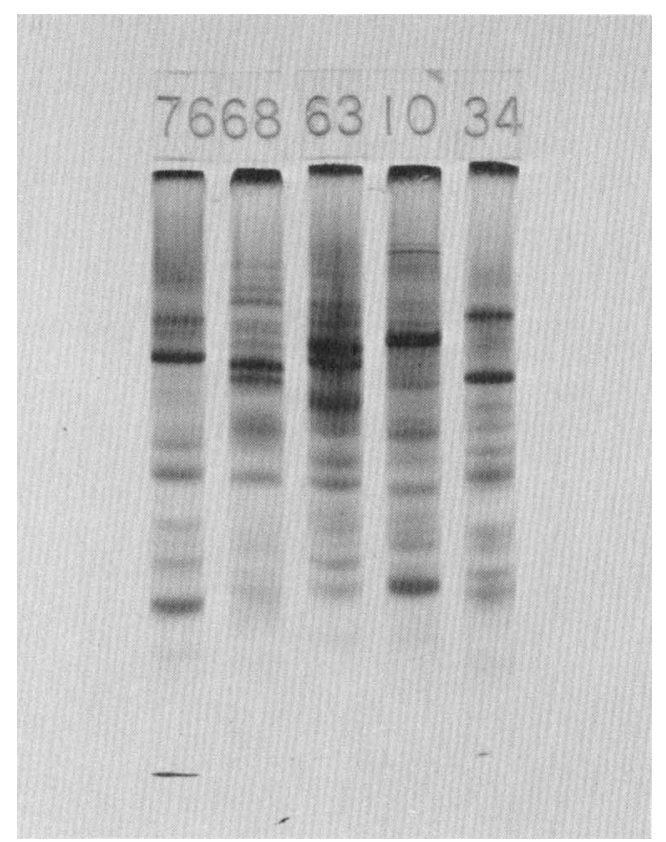

FIG. 6. Electrophoretic patterns of cell proteins from Actinobacillus equuli 13376 (76), A. seminis 15768 (68), strain 63 (63), Pasteurella haemolytica 1063 (10), and P. multocida 934 (34). femorotibial joints, or humero-radial joints of the four swine. Actinobacilli were not recovered from the nasal, pharyngeal, vaginal, or preputial secretions of the swine.

An attempt was made to isolate actinobacilli from the rectums of sows known to have vaginal infections with the organism. Vaginal and rectal samples were collected from each of 20 sows for 3 days after parturition. All hemolytic colonies resembling those produced by actinobacilli were selected and characterized biochemically. Actinobacilli were isolated from vaginal secretions of eight sows but not from any rectal swabs. Intravaginal inoculation of egg yolk fluid containing strain 192 resulted in persistent infection of the vagina in two sows. Samples of vaginal fluids collected from these sows two to three times a week remained positive throughout a 40 -day sampling period. Mucopurulent exudate was noted in the vaginal secretions and urine of one sow from the 10th to the 15 th days after inoculation, but heavy growth of a micrococcus was also obtained from the vaginal secretions of that sow during that period of time.

\section{DISCUSSION}

The microscopic characteristics and colonial morphology of the four swine strains studied closely resembled those of established species of the genus Actinobacillus. They grew facultatively with respect to oxygen but grew best under increased $\mathrm{CO}_{2}$ tension. The microaerophilic characteristic of the strains was observed in both primary and established cultures. Known species of actinobacilli reportedly are stimulated by increased $\mathrm{CO}_{2}$ tension only on initial isolation (6).

Urease production, ability to reduce nitrates, fermentation of carbohydrates without gas production, and failure to utilize citrate were biochemical characteristics of the genus Actinobacillus shared by the four strains. They resembled $A$. lignieresii, $A$. equuli, $A$. suis, and $P$. haemolytica in that they grew on MacConkey agar.

The four strains were antigenically very similar in plate agglutination and immunodiffusion tests. They were related most closely to $A$. suis and $A$. lignieresii 1388 as determined in plate agglutination tests. Results obtained by immunodiffusion indicated that the strains were related closely to $A$. seminis, $A$. suis, and all four strains of $A$. lignieresii. They were related less closely to $A$. equuli, $P$. multocida, and $P$. haemolytica. Comparison of the electrophoretic patterns of proteins extracted from 
the four strains with those extracted from established species confirmed serologic findings that the four swine strains are distinct from strains of the established species of the genus Actinobacillus.

The growth requirements and morphologic, biochemical, and antigenic characteristics of the four strains indicate that they should be classified in the genus Actinobacillus. The distinct carbohydrate fermentation, antigenic composition, and electrophoretic patterns seem sufficient to justify their placement in a new species. However, because of the present uncertain taxonomic status of several strains of actinobacilli which are related to the swine strain described in this report and because of the current lack of clear guidelines for speciation within the genus Actinobacillus, a species name is not proposed for the swine strains at this time.

The four swine strains were deposited in the American Type Culture Collection where they were assigned the following accession numbers: strain 192, ATCC 27072; strain 63, ATCC 27073; strain 145, ATCC 27074; and strain 200 , ATCC 27075. Two of the strains were deposited in the National Collection of Type Cultures (NCTC): strain 192, NCTC 10801; and strain 63, NCTC 10802. Strain 192 ( = ATCC $27072=$ NCTC 10801) is the representative strain of this group of swine organisms.

Strain 192 is a small, pleomorphic, gramnegative, rod-shaped to coccoid bacterium. It is nonmotile. Colonies are grayish white, smooth, convex, and 1 to $2 \mathrm{~mm}$ in diameter. The organism is beta-hemolytic on media containing horse blood. Growth on blood-agar is stimulated by $\mathrm{CO}_{2}$. Strain 192 grows on MacConkey agar. Acid is produced from glucose, mannitol, glycerol, inositol, sorbitol, arabinose, rhamnose, xylose, galactose, and mannose. The organism does not produce gas from glucose, or acid from lactose, sucrose, maltose, salicin, aesculin, adonitol, dulcitol, inulin, raffinose, or trahalose after 7 days of incubation. Strain 192 reduces nitrates to nitrites, produces catalase, produces $\mathrm{H}_{2} \mathrm{~S}$, and is urease-positive. It does not produce indole, alter litmus milk, utilize citrate, liquefy gelatin, or produce acetylmethylcarbinol. It is methyl red-negative. Strain 192 is antigenically very similar to three other strains $(63,200$, and 145) described in this report, and it is antigenically related to the generally accepted species of the genus Actinobacillus.

Evidence obtained so far indicates that the primary habitat of this actinobacillus is the sow vagina. This assumption is supported by the absence of the organism in rectal samples of sows with vaginal infection and the persistence of the organism in the vaginal secretions of two sows for at least 40 days. In one study of postparturient sows, we isolated organisms with biochemical and morphologic properties of the four strains described in this report from vaginal secretions of 89 of 164 sows in one herd. In another study, isolation of the organism from vaginal exudate of postparturient sows was correlated with lower litter weights at

TABLE 4. Differential biochemical and growth characteristics of actinobacilli of swine vaginal origin and strains of Actinobacillus lignieresii, $A$. equuli, $A$. suis, and $A$. seminis

\begin{tabular}{|c|c|c|c|c|c|}
\hline Determination & Swine actinobacilli & A. lignieresii & A, equuli & A. suis & A. seminis \\
\hline Number of strains $\ldots \ldots \ldots \ldots$ & 4 & 3 & 1 & 2 & 1 \\
\hline Growth on MacConkey agar ..... & $+^{a}$ & + & + & + & - \\
\hline Hemolysis of horse RBC ....... & + & - & + & + & - \\
\hline Urease $\ldots \ldots \ldots \ldots \ldots \ldots$ & + & + & + & + & - \\
\hline Indole $\ldots \ldots \ldots \ldots \ldots \ldots \ldots$ & - & - & - & - & - \\
\hline $\mathrm{H}_{2} \mathrm{~S} \ldots \ldots \ldots \ldots \ldots \ldots \ldots \ldots$ & + & + & + & + & - \\
\hline Nitrate to nitrite.$\ldots \ldots \ldots \ldots$ & + & + & + & + & - \\
\hline Catalase $\ldots \ldots \ldots \ldots \ldots \ldots$ & + & - & - & + & + \\
\hline \multicolumn{6}{|l|}{ Fermentation of carbohydrates } \\
\hline Glucose $\ldots \ldots \ldots \ldots \ldots$ & A & A & A & $\mathbf{A}$ & A \\
\hline Lactose $\ldots \ldots \ldots \ldots \ldots$ & $\mathrm{V}^{b}$ & $\mathbf{V}$ & $\mathbf{A}$ & A & $\mathbf{O}$ \\
\hline Sucrose $\ldots \ldots \ldots \ldots \ldots$ & $\mathrm{O}$ & A & $\mathbf{A}$ & A & $\mathrm{O}$ \\
\hline Maltose ......... & $\mathbf{O}$ & $\mathbf{A}$ & $\mathbf{A}$ & $\mathbf{A}$ & $\mathrm{O}$ \\
\hline Mannitol $\ldots \ldots \ldots \ldots$ & $\mathbf{A}$ & $\mathbf{A}$ & A & $\mathrm{O}$ & $\mathrm{O}$ \\
\hline Inositol $\ldots \ldots \ldots \ldots \ldots$ & A & $\mathrm{O}$ & $\mathrm{O}$ & $\mathrm{O}$ & $\mathrm{O}$ \\
\hline Sorbitol $\ldots \ldots \ldots \ldots \ldots$ & A & $\mathrm{O}$ & A & $\mathrm{O}$ & $\mathrm{O}$ \\
\hline Arabinose $\ldots \ldots \ldots \ldots \ldots \ldots$ & A & $\mathrm{O}$ & $\mathrm{O}$ & A & $\mathrm{O}$ \\
\hline Rhamnose $\ldots \ldots \ldots \ldots \ldots$ & $\mathbf{A}$ & $\mathrm{O}$ & $\mathbf{O}$ & $\mathrm{O}$ & 0 \\
\hline
\end{tabular}

${ }^{a}+$, positive; $\mathrm{O}$, no change; - , negative; $\mathrm{A}$, acid; $\mathrm{V}$, variable.

$b$ None of the four swine strains fermented lactose, but other isolates have. 
birth and at 21 days postpartum (9). However, there is no direct evidence that the organism causes lower litter weights or that it causes any other type of reproductive disorder in sows. It is apparently not pathogenic for 6-week-old swine.

Polyacrylamide electrophoresis revealed that extracts of $A$. lignieresii ATCC 13369, ATCC 13371, and ATCC 13372 were virtually identical with, but distinct from, those of $A$. lignieresii 1388 (i.e., electrophoretic patterns were similar, but some discernible differences in bands were noted). The antigenic, electrophoretic, and biochemical identity of $A$. lignieresii 1388 and $A$. suis 7038 shown in this work supports the conclusions of Mraz (7) that these organisms belong in the same species. Furthermore, limited observations made in this study indicate that strains 1388 and 7038 differ sufficiently from both $A$. ligniersii and $A$. equuli to warrant their retention in a separate species. If these observations are supported by comparisons of additional strains of each species, the name $A$. suis should be retained. Differences which can be used to distinguish $A$. lignieresii, $A$. equuli, $A$. suis, $A$. seminis, and the swine strains described in this report are presented in Table 4.

\section{ACKNOWLEDGMENTS}

This investigation was supported by U.S. Department of Agriculture Cooperative States Research Service contract 916-15-01.

Appreciation is expressed to Barbara Snook, Barbara Zimmerman, Pam Downing, and M. W. Kahn for their technical assistance. Aid provided by R. A. Packer and J. G. Holt is also gratefully acknowledged.

\section{LTERATURE CITED}

1. Ashford, W. A., and J. F. Shirlaw. 1962. A case of verrucose endocarditis in a piglet caused by an
Organism of the Actinobacillus genus. Vet. Rec. 74: 1417-1418.

2. Dickinson, A. B., and G. Mocquot. 1961. Studies on the bacterial flora of the alimentary tract of pigs. I. Enterobacteriaceae and other gramnegative bacteria. J. Appl. Bacteriol. 24:252-284.

3. Edwards, P. R., and E. L. Taylor. 1941. Shigella equirulis infection in a sow. Cornell Vet. 31:392-393.

4. Jones, J. E. T., and J. R. Simmons. 1971. Endocarditis in the pig caused by Actinobacillus equuli: A field and an experimental case. Brit. Vet. J. 127:25-29.

5. Magnusson, H. 1931. Bacterium viscosum equi (Adsersen) in suckling pigs and its relation to Bacillus polymorphus suis (Degen) in focal interstitial nephritis in swine. 11 th Int. Vet. Congr., London, Reports for Section Meetings 3:488-510.

6. Merchant, I. A., and R. A. Packer. 1967. Veterinary bacteriology and virology, 7 th ed. Iowa State University Press, Ames, Iowa.

7. Mraz, O. 1968. Reevaluation of original strains Actinobacillus suis and haemolytic strains of Actinobacillus lignieresii ATCC isolated from organs of diseased pigs. Acta Univ. Agr. Fac. Vet. 37:277-290.

8. Razin, S., and S. Rottem. 1967. Identification of Mycoplasma and other microorganisms by polyacrylamide-gel electrophoresis of cell proteins. J. Bacteriol. 94:1 807-1810.

9. Ross, R. F., L. L. Christian, and M. L. Spear. 1969. Role of certain bacteria in mastitis-metritisagalactia of sows. J. Amer. Vet. Med. Ass. 155: $1844-1852$.

10. Van Dorssen, C. A., and F. H. J. Jaartsveld. 1962. Actinobacillus suis (novo species) een bij het varken voorkomende bacterie. Tijdschr. Diergeneesk. 87:450-458.

11. Van Hemert, P., A. L. Van Wezel, and H. H. Cohen. 1964. Preparation of soluble pertussis vaccine. Nature (London) 203:774-775.

12. Wetmore, P. W., J. F. Thiel, Y. E. Herman, and J. R. Harr. 1963. Comparison of selected Actinobacillus species with a hemoly tic variety of Actinobacillus from irradiated swine. J. Infec. Dis. 113:186-194.

13. Zimmermann, V. T. 1964 . Untersuchungen über die actinobazillose des schweines. 1. Mitteilung: Isolierung und Charakterisierung der erreger. Deut. Tierärztl. Wochenschr. 7:457-461. 